研究課題別評価

1 . 研究課題名 : 有機・無機複合ナノコンポジットの動的な磁気的性質

2 . 研究者名: 阿波賀 邦夫

3. 研究のねらい：有機·無機ナノコンポジットを対象に、有機物の柔軟性と無機物の機能性を 組み合わせることにより、動的な磁気特性をもつ分子システムを構築する。

(1) 分子メモリーの研究: 高スピン $\left(\mathrm{S}=10\right.$ マンガン 12 核錯体 $\mathrm{Mn}_{12} \mathrm{O}_{12}\left(\mathrm{RCO}_{2}\right)_{16}$ は、強い磁気 異方性により、低温で磁化の向きがある一軸上で株結される。 単分子メモリーとしての 展開を図るため、クラスターの外側の有機部位を化学修飾しながら、磁化反転のダイナミ クスを解明する。さらに、トンネル顕微鏡による直接観測を行う。

（2）有機・無機層状物質の構造変化と動的磁性: 遷移金属を含む無機 2 次元磁性体に、光 や熱、化学的な雰囲気などによって構造変化を起こす有機分子をインターカレートする。 有機層に対する刺激を通じ、磁気特性の制御を試みる。

4 . 研究結果及び自己評価:

近年、分子性物質における物性探索は目覚しく、金属伝導、超伝導、強磁性、非線形光学効果、 あるいはこれらを複合したような性質が次々と見出されている。分子性磁性物質の研究において は、これまで強磁性的な性質の獲得が大きなテーマであつたが、この問題がある程度解決しつつ ある状況において、分子磁性体特有の性質を強調した展開か求められている。本研究の目的は、 有機物と無機物がナノスケールで会合した物質群を対象に、光や圧力により变化する外場応答型 の磁気特性や、ナノスケールにおける分子メモリーを開拓するというものであつた。

分子メモリ一研究の対象として選んだのがMn12核クラスター (以下 Mn12と略記) である。この分

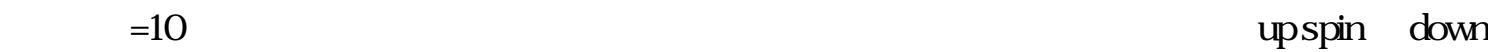
spin の状態間にポテンシャルの障壁をもっている。光のためブロッキング昷度と呼ばれる温度以 下で磁化曲線にあたかも強磁生体のようなヒステリシスループか現われることから、しばしば単 分子磁石などと呼ばれている。本研究では、Mn12の超分子化合物を合成し、关のなかで Mn12が 受ける影響を通じて Mn12の特性の解明を進めるとともに、超分子化によって Mn12の新しい側面 を引き出す努力をした。有機ラジカルとの塩の作成や、結晶溶媒を取り込んて結晶化する系の合 成に成功し、光れらの磁気特性を解析する過程で、Mn12にはブロッキング温度が異なる二成分が 存在し、多くの場合乥れらがモザイク結晶を形成することを発見した。構造解析により、両者の構造 の違いを明らかにした上で、弚れをもとにブロッキング昷度の違いについても分子論的に説明した。 Mn12に関して分子構造と磁気特性の相関を分子論的に明らかにした点は私自身気に入っている 成果であるが、残念ながら既存の Mn12を越えるような新規化合物を合成することはできなかった。 また将来の単分子メモリーを目指し、トンネル顕微鏡による Mn12の観察も試みたが、マイカや 
たが、マイカやHOPG 上では微結晶化するようで、今のところ一分子観測には成功していない。

さきが研究て新しい物質を手がけたいという気持ちから始めたのが、TTTA と呼ばれる SN 系 有機ラジカルである。前々から SN ラジカルの安定性と強い分子間相互作用に関心があったが、 TTTA のコンパクトな構造、大きな電荷分極とスピン分極に関心をもち研究をスタートさせた。TTTA はさまざまな可能性を秘奻分子で、TTTA および光の超分子化合物において、さまざまな新規物 性の発現を予感させる。TTTA に関して磁気測定を行ったところ、この分子は常磁性の高温相と反 磁生の低温相の間で一次相転移があり、しかも降温過程と昇温過程で100K 近いヒステリシスが あることが分かった。室温は290Kぐらいであろうから、これはヒステリシスループの中に含まれる。 これは、TTTA の低温相と高温相を室温て安定に単離できることを意味している。有機ラジカルで このような室温磁気双安定性力発見されたのはこれがはじめてのことである。光や圧力などでこ の双安定性を制御できれば、応用展開の期待は一気に高まるだろう。冒頭に述べたように、有機 物の磁気的性質というと有機強磁生が中心的なターゲットであった。有機強磁性体の転移温度は、 残念ながら今のところ非常に低く、室温まで引き上げるのは至難の業のように思える。しかし TTTA のように、室温で常磁性と反磁性の間を制御できればよいというのであれば、これからもいろいろ な物質が見出され弚うに思える。有機分子物性や低次元磁性体研究の分野において、室温双安 定性という全〈新しいターゲットを設定することかできたと思う。TTTA の超分子化については、この 分子を配位子として用いた錯体合成などに既に成功している。さらに興味深い構造や物性を求め て、現在研究を継続している。

\section{5 .領域総括の見解:}

磁性原子からなる通常の無機磁性体材料にはない、有機材料独自の長所をもった有機磁性体 を、有機合成技術の粋を尽くして実現しようというのが、本研究者の挑戦妨的課題であった。磁生体 が示す磁気的双安定性を外場 (光、圧力など) によって駆動するという発想も、本研究領或の趣旨 に極めてよく合致している。3年間の、試行錯誤を伴う努力によって、上記の目的の実現に端緒を 与える結果か得られ、乥の成果を国際的な研究誌に公表できたことは高く評価できる。この研究成 果が、さらに高度のチャレンジである外場応答性の有機磁性体や分子メモリーの実現に向かって の礎石となることを期待したい。

\section{6 . 主な論文等:}

1. "High- Pressure Effects on a Manganese Hexacyanomanganate Ferrimagnet with $T_{N}=29 \mathrm{~K}$ ",

K. Awaga, T. Sekine, M. Okawa, W. Fujita, S. Holmes, and G. S. Girolami,

Chem. Phys. Lett., 293, pp. 352- 356 (1998).

2. "High Pressure Effects on the Quantum Tunneling of Magnetization in $\mathrm{Mn}_{12}$ Acetate",

Y. Murata, K. Takeda, T. Sekine, M. Ogata and K. Awaga,

J. Phys. Soc. J apan, 67, pp. 30143017 (1998).

3. "Controllable Magentic Properties of Layered Copper Hydroxides, $\mathrm{Cu}_{2}(\mathrm{OH})_{3} \mathrm{X}(\mathrm{X}=$ carboxylates)", 
W. Fujita, K. Awaga and T. Yokoyama

Appl. Clay Sci., 15, pp. 281- 303 (1999).

4. "Room Temperature Magnetic Bistability in Organic Radical Crystals ",

W. Fujita and K. Awaga,

Science, 286, pp. 261- 262 (1999).

5. "Solvent- Mediated Magnetic Change in Copper- Hydroxy Intercalation Compounds",

W. Fujita and K. Awaga,

Mol. Cryst. Liq. Cryst., 334, pp. 597- 604 (1999).

6. "Magnetic Properties of Molecular Compounds of $\mathrm{Mn}_{12} \mathrm{Ph}$ ",

K. Awaga, K. Takeda and T. Inabe,

Mol. Cryst. Liq. Cryst., 335, pp. 1185- 1194 (1999).

7. "Magnetic Molecular Bistability in the Crystals of Heterocyclic Thiazyl Radicals",

W. Fujita, Y. Torigoe, K. Awaga,

Mol. Cryst. Liq. Cryst., 345, pp.161- 165 (2000).

8. “分子性ナノスケール磁性体 Mn12”

武田啓司，阿波賀邦夫，

固体物理, 34, pp. 27- 35, (1999).

9. “超微小磁性体Mn12”,

阿波賀邦夫，

パリティ, 3月号, pp. 60-64, (1999).

10. “有機強磁性と有機ラジカルの化学”,

阿波賀邦夫，

化学と工業, 5月号, pp. 590- 593, (1999).

11. "Unusual crystal structures and properties of nitronyInitroxide radicals. Possible RVB states in molecule- based magnets",

Awaga K, Wada N, Watanabe I, Inabe T

Phil. Trans. R. Soc. London A, 357, pp.2893 2921 (1999).

12. "室温で磁気双安定性を示す分子結晶"

藤田渉, 阿波賀邦夫，

固体物理, 35, pp. 813 818, (2000). 